\title{
Human Heredity
}

\section{Introduction}

\author{
Derek Gordon $^{a}$ Marcella Devoto ${ }^{b}$ \\ ${ }^{a}$ Department of Genetics, Rutgers, The State University of New Jersey, Piscataway, N.J., \\ ${ }^{\text {b} T h e ~ C h i l d r e n ' s ~ H o s p i t a l ~ o f ~ P h i l a d e l p h i a, ~ D i v i s i o n ~ o f ~ H u m a n ~ G e n e t i c s, ~ P h i l a d e l p h i a, ~ P a ., ~ U S A ~}$
}

We are delighted to present this special issue celebrating the anniversary of the Transmission Disequilibrium Test (TDT) [1, 2]. In this introduction, we list a few reasons why we think that the TDT belongs in the pantheon of great statistical genetics methods.

(1) The method is simple. For trios in which the father, mother, and affected child all have genotype data, the TDT may easily be calculated by counting the number of times a heterozygous parent transmits one allele and not the other, across all trios. These numbers may be tallied in a table, as was demonstrated in the 1993 publication [see table 2 of 1]. The counts are entered into a formula to calculate the TDT statistic, and for a sufficiently large sample size, the significance of the statistic is determined using the null distribution of the TDT, which is a central chi-square with 1 degree of freedom.

(2) The method is widely used. The TDT has been applied to hundreds of studies involving the mapping of disease genes. Genetic disorders to which TDT methods have been applied include insulin-dependent diabetes mellitus [1], psoriasis [3-6], Graves disease [7], schizophrenia [8,9], bipolar disorder [10], autism [11, 12], and many others. The method is considered so essential to family-based association testing that it is routinely implemented in comprehensive statistical genetics analysis programs (e.g., GENEHUNTER [13], PLINK [14]).

\section{KARGER}

Fax +41613061234

E-Mail karger@karger.ch

www.karger.com
(C) 2008 S. Karger AG, Basel

0001-5652/08/0662-0065\$24.50/0

Accessible online at:

www.karger.com/hhe
(3) The method has inspired several methodological extensions/investigations. Since the publication of the original TDT statistic in 1993, there have been hundreds of papers investigating methodological issues regarding the TDT. If one types the key words 'transmission disequilibrium test' and 'method' into Pubmed, over 200 papers are returned (as of February, 2008). Extensions of the TDT method include those that allow for untyped parents [15], multiple alleles at a locus [16, 17], discordant sibs [18], quantitative traits $[19,20]$, and haplotypes [21], to name a few.

In this issue of Human Heredity, we present additional methodological and empirical investigations of the TDT statistic. We hope you enjoy reading the articles and that you find them useful in your research.

Finally, we wish to thank Drs. Warren Ewens and Richard Spielman for their guidance and support of this special issue. We dedicate this issue to them and to Dr. Ralph McInnis.
Derek Gordon, $\mathrm{PhD}$

Department of Genetics, Rutgers, The State University of New Jersey

145 Bevier Road, Rm 128

Piscataway, NJ 08854 (USA)

Tel. +1 732445 3386, Fax +1 732445 1147, E-Mail gordon@biology.rutgers.edu 


\section{References}

1 Spielman RS, McGinnis RE, Ewens WJ: Transmission test for linkage disequilibri$\mathrm{um}$ : the insulin gene region and insulin-dependent diabetes mellitus (IDDM). Am J Hum Genet 1993;52:506-516.

2 Spielman RS, Ewens WJ: The TDT and other family-based tests for linkage disequilibrium and association. Am J Hum Genet 1996; 59:983-989.

3 Hewett D, Samuelsson L, Polding J, Enlund F, Smart D, Cantone K, See CG, Chadha S, Inerot A, Enerback C, Montgomery D, Christodolou C, Robinson P, Matthews P, Plumpton M, Wahlstrom J, Swanbeck G, Martinsson T, Roses A, Riley J, Purvis I: Identification of a psoriasis susceptibility candidate gene by linkage disequilibrium mapping with a localized single nucleotide polymorphism map. Genomics 2002;79: 305-314.

4 Huffmeier U, Lascorz J, Traupe H, Bohm B, Schurmeier-Horst F, Stander M, Kelsch R, Baumann C, Kuster W, Burkhardt H, Reis A: Systematic linkage disequilibrium analysis of SLC12A8 at PSORS5 confirms a role in susceptibility to psoriasis vulgaris. J Invest Dermatol 2005; 125:906-912.

5 Helms C, Cao L, Krueger JG, Wijsman EM, Chamian F, Gordon D, Heffernan M, Daw JA, Robarge J, Ott J, Kwok PY, Menter A, Bowcock AM: A putative RUNX1 binding site variant between SLC9A3R1 and NAT9 is associated with susceptibility to psoriasis. Nat Genet 2003;35:349-356.
6 Helms C, Saccone NL, Cao L, Daw JA, Cao K, Hsu TM, Taillon-Miller P, Duan S, Gordon D, Pierce B, Ott J, Rice J, FernandezVina MA, Kwok PY, Menter A, Bowcock AM: Localization of PSORS1 to a haplotype block harboring HLA-C and distinct from corneodesmosin and HCR. Hum Genet 2005;118:446-476.

7 Tomer Y, Concepcion E, Greenberg DA: A $\mathrm{C} / \mathrm{T}$ single-nucleotide polymorphism in the region of the CD40 gene is associated with Graves' disease. Thyroid 2002;12:11291135.

8 Dubertret C, Hanoun N, Ades J, Hamon M, Gorwood P: Family-based association study of the serotonin-6 receptor gene (C267T polymorphism) in schizophrenia. Am J Med Genet B Neuropsychiatr Genet 2004;126:1015.

9 Dubertret C, Hanoun N, Ades J, Hamon M, Gorwood P: Family-based association study of the 5-HT transporter gene and schizophrenia. Int J Neuropsychopharmacol 2005; 8:87-92.

10 Shi J, Hattori E, Zou H, Badner JA, Christian SL, Gershon ES, Liu C: No evidence for association between 19 cholinergic genes and bipolar disorder. Am J Med Genet B Neuropsychiatr Genet 2007;144:715-723.

11 Dutta S, Das S, Guhathakurta S, Sen B, Sinha S, Chatterjee A, Ghosh S, Ahmed S, Ghosh S, Usha R: Glutamate Receptor 6 Gene (GluR6 or GRIK2) Polymorphisms in the Indian Population: A Genetic Association Study on Autism Spectrum Disorder. Cell Mol Neurobiol 2007;27:1035-1047.

12 Torres AR, Maciulis A, Stubbs EG, Cutler A Odell D: The transmission disequilibrium test suggests that HLA-DR4 and DR13 are linked to autism spectrum disorder. Hum Immunol 2002;63:311-316.
13 Kruglyak L, Daly MJ, Reeve-Daly MP, Lander ES: Parametric and nonparametric linkage analysis: a unified multipoint approach. Am J Hum Genet 1996;58:1347-1363.

14 Purcell S, Neale B, Todd-Brown K, Thomas L, Ferreira MA, Bender D, Maller J, Sklar P, de Bakker PI, Daly MJ, Sham PC: PLINK: a tool set for whole-genome association and population-based linkage analyses. Am J Hum Genet 2007;81:559-575.

15 Curtis D, Sham PC: A note on the application of the transmission disequilibrium test when a parent is missing. Am J Hum Genet 1995; 56:811-812.

16 Bickeboller H, Clerget-Darpoux F: Statistical properties of the allelic and genotypic transmission/disequilibrium test for multiallelic markers. Genet Epidemiol 1995;12:865870.

17 Cleves MA, Olson JM, Jacobs KB: Exact transmission-disequilibrium tests with multiallelic markers. Genet Epidemiol 1997;14: 337-347.

18 Spielman RS, Ewens WJ: A sibship test for linkage in the presence of association: the sib transmission/disequilibrium test. Am J Hum Genet 1998;62:450-458.

19 Allison DB: Transmission-disequilibrium tests for quantitative traits. Am J Hum Genet 1997;60:676-690.

20 Rabinowitz D: A transmission disequilibrium test for quantitative trait loci. Hum Hered 1997;47:342-350.

21 Dudbridge F, Koeleman BP, Todd JA, Clayton DG: Unbiased application of the transmission/disequilibrium test to multilocus haplotypes. Am J Hum Genet 2000;66:20092012. 